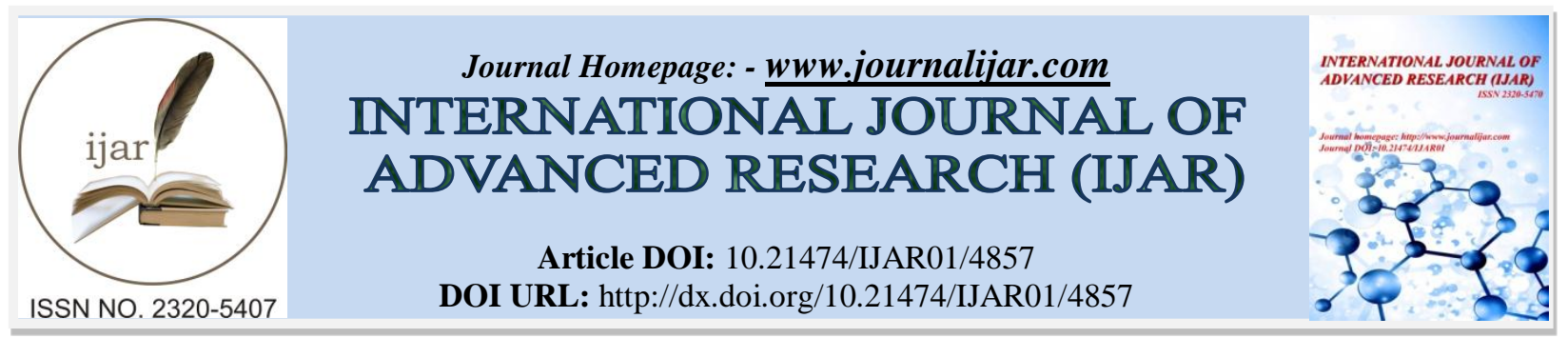

RESEARCH ARTICLE

\title{
AN INTEGRATIVE MODEL FOR MEASURING COMBAT READINESS.
}

\section{Kwong Fook Wen ${ }^{1}$, Norazman Mohamad Nor ${ }^{2}$, Jegak Uli ${ }^{2}$, Lee Lai Soon ${ }^{3}$ and Endry Nixon ${ }^{1}$.}

1. Malaysian Army Headquarters, Jalan Padang Tembak, 50634 Kuala Lumpur, Malaysia .

2. National Defence University of Malaysia, Sungai Besi Camp, 57000 Kuala Lumpur, Malaysia.

3. Faculty of Science, Universiti Putra Malaysia, 43400 UPM Serdang, Selangor, Malaysia.

\section{Manuscript Info}

...........................

Manuscript History

Received: 15 May 2017

Final Accepted: 17 June 2017

Published: July 2017

Key words:-

combat readiness, combat power, tangible and intangible element, armed force.

\section{Abstract}

Measuring combat readiness in an armed force involves the measures of tangible and intangible elements of combat power. However, the mathematical models and formulae used for the measure are focused mainly on either the tangible or the intangible elements. The purpose of this research is to provide an integrative model that provides a comprehensive measure of the combat readiness depicting its status of capability and operability by incorporating the tangible and intangible elements of combat power. The research adopted a quantitative approach using post-positivism paradigm philosophy and quantitative method design. The survey method research design looked into the variables causal effect of capability, morale and quality of life on combat readiness through a non-experimental correlation design survey questionnaire. Probability proportionate stratified random sampling technique was used for data collection. Structural Equation Modeling (SEM) was used for the statistical treatment as it catered for the multiple regression analyses of factors to predict the combat readiness of an armed force. The result of the research provides a model that an armed force could use to predict the function of combat readiness or any of its variables by using the formula $Y=\beta_{1} X_{1}+\beta_{2} X_{2}$ $+\beta_{3} X_{3}$ whereby the tangible and intangible elements of combat power contribute towards the measure of combat readiness with regression weights of the independent variables capability $\left(\beta_{1}\right)$, morale $\left(\beta_{2}\right)$ and quality of life $\left(\beta_{3}\right)$. The minimum for the model is achieved in reaching a convergent solution by yielding a Chi-square goodness-offit indices of good-fit values. The results enable an armed force to use the combat readiness measurement model in prioritizing the allocation of resources for its tangible and intangible elements of combat power during its policy-setting and decision making process. As such, the integrative model can be used to address shortfalls and augment its combat readiness.

Copy Right, IJAR, 2017,. All rights reserved.

\section{Introduction:-}

Combat readiness is of utmost importance to an armed force as it is often related to its ability to conduct operations. The status of combat readiness is also one of the means of deterrence against potential aggressors. Unlike measuring performance in profit-oriented organizations whereby instruments to judge and measure performance are generally 
agreeable and acceptable by the organizations, there are no standard instruments and measures for combat readiness of a military organization. Therefore, an integrative model would provide a comprehensive approach that measures the possible elements contributing to the combat readiness. Hence, the aim of this research was to develop an integrative model to measure the combat readiness of an armed force. Consequently, the research focused on the objectives of determining the tangible and intangible elements of combat power for the measuring of the combat readiness, formulating a mathematical model that incorporates tangible elements with the intangible elements of combat power for the measuring of the combat readiness, determining the relationship between the determined intangible and tangible elements of combat power with combat readiness and identifying the correlation between the tangible and intangible elements of combat power with combat readiness.

Thus, this paper looks into the need for an integrative model to measure the combat readiness of an armed force. First, it establishes the historical background and theories underpinning combat readiness. Then, it surveys the different approaches used for the measure of combat readiness. Then, models that were developed for measuring specific aspect of combat readiness are presented. It then dwells on the findings and discussion of the survey. Finally, the paper ends with the conclusion and recommendation for further research.

\section{Background:-}

Sun Tzu, who lived from 544-496 BC, pointed out the importance of readiness when he said it is the art of war not to assume the enemy will not come, but rather to rely on one's readiness to receive him (Griffith, 1971). Similarly, Clausewitz (1874) also emphasized the need of readiness when he mentioned that the term 'art of war' or 'science of war' is related to the "pattern and preparation and the mode of using arms, construction of fortifications and entrenchments, organism of an army and the mechanism of its movements, the end and aim of them all was the establishment of an armed force fit for use in war". The contemporary theories of readiness are found to have developed form these older theories. For example, Betts (1995) described readiness as the state of operational status of the assets ready for use at its optimal or designed parameters. Likewise, the United States Department of Defence (2010) linked the theory of military capability to the ability to achieve a specified wartime objective (win a battle, destroy a target set) and it included readiness, sustainability components of force structure and modernization. Readiness was also denoted as the ability of the United States military forces to fight and meet the demand of its national military strategy that encompasses the strategic, operational and tactical perspective.

The status of combat readiness can only be known if there is a systematic assignment of numerical value (quantitative) or verbal descriptors (qualitative) given to combat readiness (Nunnally \& Bernstein, 1994). Similarly, Hair et al., (2011) said that measurement involves the process of assigning numbers to a variable based on a set of rules. One of the reasons for the unavailability of a standardized instrument for the measure of combat readiness in military forces is due to different understandings of the term on combat readiness. On this aspect, Rosenberger (1999) and Nor \& Wand (2001) argued that armies have been measuring the combat readiness based on the presence or absence of certain resources. Thus, it is important to have an integrative model for measuring the tangible and intangible elements of combat power. Currently, there are models that are doing a tremendous job in measuring the combat readiness of armed forces based on the measure of the tangible capability elements of combat power. The measure of its combat readiness is equated with measures based on tangible elements of capability such as firepower, communication, mobility, logistics, human resource, training and etc. Capability of a military organization is described as the state of preparedness of a unit to perform the mission for which it is organized or it may be stated as an aggregate of material and morale aspects of a military force (Voith, 2001; Andrew \& Shambo, 1980). Thus, the elements of capability include military equipment and soldier's skill and morale. Additionally, research also shows that capability, especially in military organizations does not only relate to infrastructure capability but also includes morale of soldiers in performing a military mission (Bester \& Stanz, 2007; Gal, 1986; Schuman et al, 1996). Studies have also identified that combat readiness in a military organization also hinges heavily on the intangible factors such as morale and quality of life (Bester \& Stanz, 2007; Gal, 1986; Schuman et al., 1996). Similarly, studies have also found that Quality of life, the other intangible element of combat power also provides indication of combat readiness of individuals. Based on the body of literature, the domains used on quality of life include: financial; housing; health and personal safety; family life; relation with superiors, subordinates and colleagues; neigbourhood community; work environment and career development (Verwayen, 1980; Zapf, 1980; McKennell, 1978). On the other hand, there were other researchers and authors who equated combat readiness with psychosocial elements namely: Knorr (1956), Richardson (1978), Summers (1998), Ingraham \& Manning (1981); MacDonough (1991), Schumm et al., (1996), Vinson (2000), Kruys (2001) and Van Vuurun (2000). 
Based on the reviewed literature, combat readiness could be construed as comprising of two interdependent dimensions namely the tangible and intangible elements of combat power. Unfortunately, the measuring of combat readiness in the armed forces is still lacking in comprehensiveness. There is a gap in the measures adopted to gauge combat readiness as it does not include the measure of both the tangible and intangible elements of combat power. Hence, this research provides an integrative model that gives a comprehensive measure of the combat readiness of an armed force which includes both the tangible and intangible elements of combat power.

\section{Theories Underpinning Combat Readiness:-}

The theories underpinning the measure of combat readiness are related to the theory of combat readiness and the theories concerning the tangible elements and the intangible elements of combat power that form the measure of combat readiness. The theoretical basis of the studies on combat readiness hinges on the doctrinal concept of fighting power practiced by armed forces. In a typical fighting power model, the physical component of fighting power is the means to fight in the battlefield operating systems. The means to fight comes from its capability elements comprising: manoeuvre; fire support; information operations; intelligence; surveillance and reconnaissance; mobility; air defence; command and control; and combat service support.

The literature on combat readiness indicates that the theories underpinning combat readiness hinge on the different conceptualization of various definitions coined for combat readiness. As such, the approach for survey on this topic has to adopt selected definitions and concepts of combat readiness that could provide a comprehensive measure for the combat readiness. Thus, the identified factors and elements of combat readiness from these definitions would then act as the basis for the formulation of the integrative model for measuring combat readiness.

The theories of combat readiness are used differently by different armed forces. For example, Yurechko (2007) said that the Union of Soviet Socialist Republics (the former great power of the Eastern World) had termed combat readiness as the ability of troops (forces) in any and all situational conditions, to commence military actions when scheduled and successful in accomplishing assigned missions. It was determined by the fighting efficiency and battle-worthiness of troops (forces), by a correct understanding of their commanders, staff and political agencies, by prompt and timely preparation for forthcoming operations, and by foreseeing possible situation changes. The degree of combat readiness in peacetime would ensure a rapid shifting of troops (forces) to a war alert status and organized commencement of military operations, and in wartime the ability to accomplish immediate execution of assigned combat mission. An important aspect on combat readiness that could be drawn from the studies by Yurechko (2007) shows that a high state of readiness of an armed forces must be maintained in order to deploy expeditiously and promptly for repulsing enemy surprised attack, delivering retaliatory attack and accomplishing assigned mission encompassing offensive operations. With the demise of the Union of Soviet Socialist Republics, Russia put similar emphasis on the maintenance of combat readiness as reflected in the Interfax report: Russia and Commonwealth Independent States (CIS) Military Daily (Moscow) on 4 February 2011 that the increase in officer's numbers will raise the army's combat readiness (Interfax, 2011). It has also conducted surprised inspections on combat readiness as reported in Moscow Times on June 14, 2016 (Moscow Times, 2016).

The varying theories of combat readiness suggest that the capability of an armed force, its condition, psychological status and other elements could be used to measure combat readiness. Thus, these different theories and understanding of combat readiness require different approaches of measuring combat readiness in accordance with their respective meanings.

\section{Approaches For Measuring Combat Readiness;-}

The theories underpinning combat readiness allude to the facts that there are different approaches and variables used for the measure of combat readiness. Clearly, different defence forces measure combat readiness differently. For example, the United States Field Manual (FM) 100-11 specify an approach that measure readiness involving tangible and intangible factors (United States Department of Army, n.d.). Some of these factors are quantifiable while others are subjective. The tangible elements for force readiness factors that can be objectively measured are the status of personnel and the status of equipment. Where else the subjective determination is the factors of morale, cohesion and quality of leadership. The United States Department of Defence (2010) has also been seeking other approaches to enhance their instruments for measuring combat readiness. In the Chairman Joint Chief of Staff's Guide to the Chairman's Readiness System, this approach provides the design to measure the preparedness of the United States' military to attain objectives outlined in their National Military Strategy (NMS). It involves the measure of preparedness done by unit reporting (force readiness reporting) and Joint Combat Capability 
Assessment. The Chairman's Readiness System measure of combat readiness takes into account the elements of combat power that would enable a force to engage in a given mission.

The different approaches adopted by different armed forces specify different variables which contribute towards the measures of combat readiness. Mumford (1976) conducted a study that focused on the nature and strength of the relationship between human resource management and operational readiness to establish the co-relationships of variables for measuring readiness. Readiness was measured by refresher training on navy ships under the charge of the United States Navy Personnel Research and Development Centre, San Diego, California. In this study, the dependent variable was the scores earned by ships during the refresher training which was used as the dependent measure of combat effectiveness or readiness for combat. On the other hand, the independent variables were the indices on the human resource survey that were used as the independent measures of personal and organizational behaviour. The results of the study indicated the correlation coefficient between refresher training and those perceptions assessed by the human resource management survey. The instrument used for the human resource management survey was a modification of the survey of organization adopted by the University Of Michigan Institute Of Social Research (Taylor \& Bowers, 1972). It hinged on the Likert Organizational Behaviour Model (Likert, 1967). Based on the studies done, the approach and questionnaires used by Mumford (1976) were adapted to measure the extent of correlation of the tangible and intangible elements for the integrative model to measure combat readiness of an armed force for this research. Likert scales were also used to quantify the survey for the intangible factors affecting the combat readiness.

Morale stands out amongst the intangible elements that affect the combat readiness. Gal (1986) pointed out that Lewis Guttman produced examples of one of the earliest unit morale surveys in the Israeli Army in 1949. Guttman used questionnaires that looked at fundamental concerns involving satisfaction with living arrangements in barrack. Subsequently, this morale related research was developed into research on combat readiness when the Israeli Defence Force became more involved in combat actions. Gal (1986) used a set of questionnaires known as Combat Readiness Morale Questionnaire (CRMQ) to determine personal and unit level morale for troops. The sample of the population used in the questionnaire survey involved 1,200 Israeli Defence Force (IDF) troops that were about to be deployed to Lebanon in 1981 for a contingent operation. The key results obtained from factor analysis identified two items that were very much related with personal and perceived morale; First, on perceived unit togetherness and second, on relationships with commander. Additionally, the factors analysis of 30 items in the questionnaire indicated eight factors that caused $52 \%$ of the variance for his sample. The eight factors were: confidence in senior commanders, confidence in one's self, team and weapons, unit cohesion and morale, familiarity with mission and frontage, confidence in immediate commanders, enemy evaluation, the legitimacy of the war and finally worries and concerns. In his studies, Gal (1986) concluded those morale and unit climates are the two higher-order factors as predictors to combat readiness. Hence, the factors being considered in this survey and the CRMQ used were adapted as instrument for the integrative model to measure the morale factors of troops in an armed force. Additionally, the considerations of culture and work ethics of different armed forces have also been taken into consideration in preparing the items for the questionnaire.

Continuing with his previous studies on Morale, Gal \& Manning (1987) researched on the components of morale by doing a cross national comparison. They administered the questionnaires used for Israeli Defence Forces' soldiers stationed along the border of Lebanon $(n=1,270)$ to the personnel from two United States (U.S.) Army Armoured Cavalry Squadrons ( $n=660)$ located at two different locations. The first squadron was located on the East German Border in U.S. Army Europe (USAREUR) and the second squadron was in the Continental U.S. (CONUS). The survey was to evaluate morale, cohesion and soldiers' perception of unit readiness for combat. The three sets of data obtained were structured across three factors, namely group factor, leadership factor and individual factors (personal and professional). Using inter-item correlations and factors analysis, the studies discovered that the structure of morale was generally similar for the U.S. units and the IDF samples. However, there were apparent differences on relationship between morale and contribution to national security, confidence in senior commanders and confidence in weapons. The studies also found that the USAREUR unit resembled the IDF sample more than the sample from CONUS due to situational characteristics of proximity to enemy and/or battlefield. The studies concluded that the determinants of morale is relatively similar across armies although these determinants are influenced by national and situational characteristics. The instruments used by Gal \& Manning (1987) for the IDF and the U.S. proved that it is useful in identifying the determinants of morale for the integrative model to measure combat readiness. 
Intangible factors are also considered by the Royal Netherlands Armed Forces as of importance in their maintenance of combat readiness. Meijer \& Vries (2005) conducted a study on the psychosocial perspective in maintaining combat readiness in the Royal Netherlands Armed Forces. They acknowledged that combat readiness of military forces hinges on many factors such as material readiness, combat exposure, personnel readiness and training level. The aim of the study was to explore how systemic and systematic psychosocial interventions contribute to the operational readiness of combat units. Three research questions were addressed in the studies: First, which psychosocial factors contribute to combat readiness? Second, what is the implication of a systematic and systemic approach to combat readiness factors? Third, how can the Ministry of Defence use a systematic and systemic approach to enhance combat readiness? A multi-method approach was used to answer the research questions. The multi-method approach included a survey onto eight seagoing units of the Royal Netherlands Navy, conducting an expert panel on psychosocial factors of combat readiness and by case studies of deployments of operational units of the Netherlands Armed Forces. The studies found that training and personnel readiness formed the human factors in the maintenance of combat readiness. Personnel readiness was predicted by the quality and quantity of the personnel aboard and the time they are aboard of the combat unit. Additionally, the studies also found that psychosocial factors contributed to maintenance of combat readiness. Meijer \& Vries (2005) concluded that human factors and systematic as well as systemic psychosocial intervention are important for the maintenance of combat readiness. Based on these studies, the approach used to derive at a comprehensive integrative model of combat readiness took cognizance of the human factors in addition to that of material and capability readiness.

\section{Models For Measuring Combat Readiness:-}

Based on the studies and research done on identifying instruments to measure combat readiness, there were different models developed for measuring different specific aspect of combat readiness. The varying models used are in view that military forces are required to operate in different operations that are diverse and multi-spectrum in nature. It is also because of the many diverse meanings of combat readiness being used. Table 1 shows some of the models that have been developed to measure specific aspects of combat readiness.

Table 1:- Models developed for measuring specific aspect of combat readiness.

\begin{tabular}{|c|c|}
\hline $\begin{array}{l}\text { Type of Combat Readiness } \\
\text { Model }\end{array}$ & Focus of the Model \\
\hline $\begin{array}{l}\text { Peace Support Operation } \\
\text { Model } \\
\text { (Bester \& Stanz, 2007) }\end{array}$ & $\begin{array}{l}\text { The peace support operation model of combat readiness focuses on psychosocial } \\
\text { dimension and material dimension. The domains of the model are confidence and } \\
\text { social trust, worries and concern as well as morale. The sub-domains of morale are } \\
\text { cohesion, esprit de corps, general willingness, discipline and common goals. }\end{array}$ \\
\hline $\begin{array}{l}\text { Counter-terrorism } \\
\text { Operation Model } \\
\text { (Filjak \& Denacic, 2005) }\end{array}$ & $\begin{array}{l}\text { The counter-terrorism operation model involves the construct of "classic" } \\
\text { psychological combat readiness involves terrorism fighting readiness. The items } \\
\text { factor structure are grouped into three factors namely, information availability, } \\
\text { fighting readiness estimation and prediction of terrorism fighting success. }\end{array}$ \\
\hline $\begin{array}{l}\text { Quality of Life Model } \\
\text { (Andrews \& Withey, 1976; } \\
\text { Blishen and Atkinson, 1980; } \\
\text { Wolosin, Wilcove \& } \\
\text { Schwerin, 2003; Campbell, } \\
\text { Converse \& Rodgers, 1976; } \\
\text { Nkewu, 2014) }\end{array}$ & $\begin{array}{l}\text { The quality of life model looks into quality of life assessments that combine both the } \\
\text { measures of relationships of domains and the perceived quality of life. Its domains } \\
\text { involve financial situation, job and neighbourhood satisfaction, housing, health, } \\
\text { friendships, marriage, family life, amount of education and savings, personal life, } \\
\text { relations with other people, economics (income and living standard), the local area } \\
\text { (safety, security), the larger society and others (religions, faith, personal growth, } \\
\text { autonomy, environmental mastery, confidence, morale, cohesion and unit discipline. }\end{array}$ \\
\hline $\begin{array}{l}\text { Human Dimension Model } \\
\text { (Goyne, 2004; Johnston et } \\
\text { al., 2002; Murphy \& Farley, } \\
\text { 2000) }\end{array}$ & $\begin{array}{l}\text { The human dimension model involves a theoretical model integrating scales to } \\
\text { measures constructs rather than individual items measuring opinions. The factors } \\
\text { being measured involve cohesion, organizational commitment, psychological well- } \\
\text { being, satisfaction and quality of life. }\end{array}$ \\
\hline $\begin{array}{l}\text { Morale Measurement } \\
\text { Model } \\
\text { (Fils, 2006; Shamir et al., } \\
\text { 2000; Siebold \& Manning, } \\
\text { 1999) }\end{array}$ & $\begin{array}{l}\text { The morale measurement model uses a standardized sociological survey instrument. } \\
\text { The domains of the model include satisfaction with the mission, morale level, } \\
\text { discipline and intercultural relationships, soldiers' experience, leader's tenure, } \\
\text { leader's confidence in the unit, soldiers' confidence in the leader, unit discipline, } \\
\text { espirit de corps and unit cohesion. }\end{array}$ \\
\hline $\begin{array}{l}\text { Hierarchical Linear } \\
\text { Modeling } \\
\text { (Griffth, 2002) }\end{array}$ & $\begin{array}{l}\text { The hierarchical linear model involves a multilevel analysis of cohesion's relation to } \\
\text { stress, well-being, identification, disintegration, and perceived combat readiness. }\end{array}$ \\
\hline
\end{tabular}


The different models and different focuses of the models indicate that many variables and factors could be taken as elements in the development of the integrative model to measure the combat readiness of an armed force. Variables identified could be analyzed using different tools so as to derive at the best items and factors for the integrative model measuring the combat readiness. This would provide normative data for comparisons between units, formations and a cross-section of the armed force in the integrative model of combat readiness. Though there are many developed models that can be used to measure combat readiness of an armed force, an integrative model for the measure of combat readiness would provide a more comprehensive status of readiness in the armed force.

\section{The Theoretical Framework For Measuring Combat Readiness:-}

Based on the survey, the reviewed literature indicates that the key terms for the measure of combat readiness revolve around the tangible and intangible elements of combat power. The tangible element of combat power comprises the domain of capability. Where else the intangible element of combat power consists of morale and quality of life. Each of the identified domain could be further elaborated through different sub-domains. Table 2 below illustrates the different descriptions of the attributes of combat readiness that the theoretical framework hinges on (Kwong et al., 2013).

The conceptualization of the identified domains and the utilization of appropriate measuring instrument produced a theoretical framework for this research as shown in Figure 1 (Kwong et al., 2014). Consequently, the quantitative outcome of the theoretical framework is an integrative model based on the formula whereby combat readiness is a function of capability, morale and quality of life which is reflected in the equation:

Combat Readiness $=f($ Capability.Morale. Quality of life $)$.

Table 2:- Domain, sub-domain of combat readiness and its interpretation

\begin{tabular}{|c|c|c|}
\hline Domain & Sub-domain & Description selected \\
\hline \multirow[t]{6}{*}{ Capability } & Human resource & $\begin{array}{l}\text { The number of individuals who make up the workforce of an } \\
\text { organization. }\end{array}$ \\
\hline & Firepower & $\begin{array}{l}\text { The amount of power which may be delivered by a position, units or } \\
\text { weapons. }\end{array}$ \\
\hline & Mobility & $\begin{array}{l}\text { A quantity or capability of military forces which permits then to move } \\
\text { from place to place while retaining the ability to fulfill their primary } \\
\text { function. }\end{array}$ \\
\hline & Communication & $\begin{array}{l}\text { The total number of equipment for transmission of information of any } \\
\text { kind from one person or place to another. }\end{array}$ \\
\hline & Logistics & $\begin{array}{l}\text { The availability of logistics support (ammunition, fuel, food, spare } \\
\text { parts) for maintenance of forces. }\end{array}$ \\
\hline & Training & $\begin{array}{l}\text { The frequency of instruction of personnel to enhance their capacity to } \\
\text { perform specific military functions and tasks as well as the exercise of } \\
\text { one or more military units conducted to enhance their combat } \\
\text { readiness. }\end{array}$ \\
\hline \multirow[t]{6}{*}{ Morale } & Cohesion & $\begin{array}{l}\text { The person-to-person bonding within the primary groups of soldiers in } \\
\text { a particular unit. }\end{array}$ \\
\hline & Willingness to deploy & $\begin{array}{l}\text { A soldier's willingness or motivation to participate in military } \\
\text { operations. }\end{array}$ \\
\hline & $\begin{array}{l}\text { Confidence in } \\
\text { leadership }\end{array}$ & $\begin{array}{l}\text { The degree to which subordinates have confidence and trusts in their } \\
\text { leaders. }\end{array}$ \\
\hline & Espirit de corps & $\begin{array}{l}\text { The feeling of pride that goes along with the sense of belonging, } \\
\text { fellowship and loyalty between comrades, units, formations and Corps } \\
\text { in times of peace and war. The bonding between soldiers and their } \\
\text { secondary groups beyond their primary group bonding that relates the } \\
\text { soldiers to the institutions of the unit. }\end{array}$ \\
\hline & Discipline & $\begin{array}{l}\text { A controlled behavior to obey orders as issued by a legitimate } \\
\text { authority. The degree to which soldiers comply with military rules and } \\
\text { regulations. }\end{array}$ \\
\hline & Motivation & $\begin{array}{l}\text { Motivation for combat can be understood as "the impulse that compels } \\
\text { the soldier to face the enemy on the battlefield" or "the determination }\end{array}$ \\
\hline
\end{tabular}




\begin{tabular}{|l|l|l|}
\hline & & $\begin{array}{l}\text { that induces soldiers to fight, in spite of the adversities and the } \\
\text { inherent dangers of war". }\end{array}$ \\
\hline Quality of Life & Work & $\begin{array}{l}\text { Safe and conducive working environment that results in high work } \\
\text { satisfaction. }\end{array}$ \\
\hline & $\begin{array}{l}\text { Neighbourhood and } \\
\text { Shelter }\end{array}$ & $\begin{array}{l}\text { High quality and standard housing facilities and infrastructure, } \\
\text { encompassing the necessary maintenance services. }\end{array}$ \\
\hline & Education & $\begin{array}{l}\text { The systematic instruction of individuals in subjects that will enhance } \\
\text { their knowledge of the science and art of war. Provide access to } \\
\text { tertiary education. }\end{array}$ \\
\hline & $\begin{array}{l}\text { The interaction between military installations and their surrounding or } \\
\text { nearby civilian communities. The provision of community facilities in } \\
\text { bases that are of quality and standard. }\end{array}$ \\
\hline & $\begin{array}{l}\text { High quality and readily available medical and health services to } \\
\text { needy servicemen. }\end{array}$ \\
\hline & $\begin{array}{l}\text { "Spiritual fitness" is the core values, beliefs, and the source of one's } \\
\text { meaning in life as well as the provision of psychological and } \\
\text { counselling services. }\end{array}$ \\
\hline & Family and friends & Family unity and supports from friends. \\
\hline
\end{tabular}

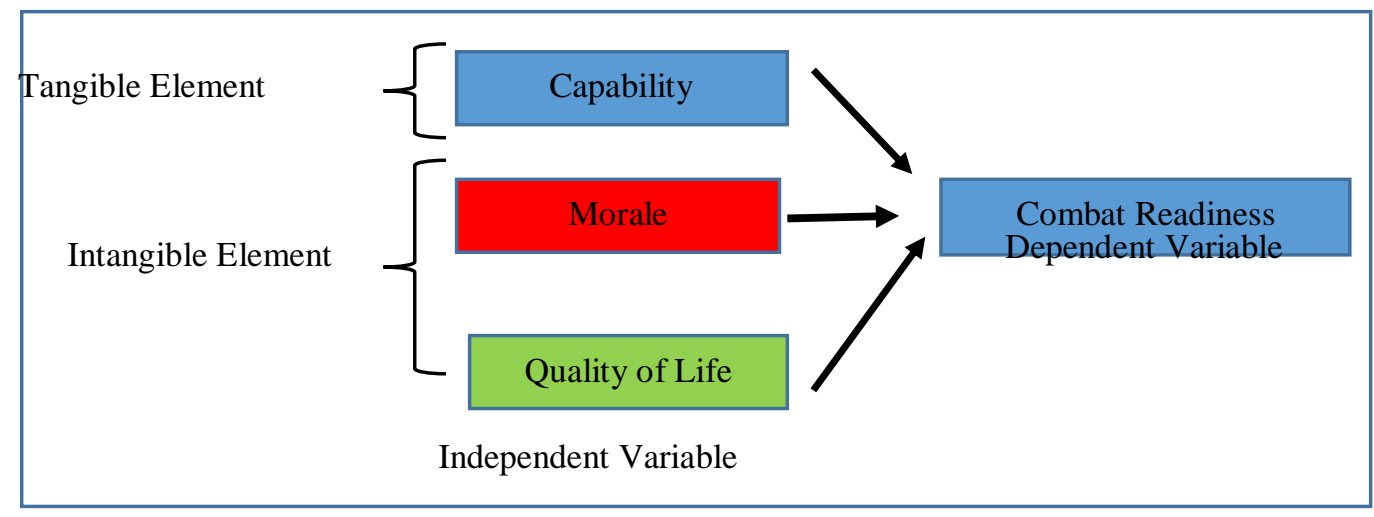

Figure 1:- Theoretical framework of combat readiness

\section{Method:-}

\section{Methods of Research:-}

This research adopted a quantitative method of research based on post-positivism philosophy in providing the best understanding for the measure of combat readiness. The quantitative approach used in this research has included structural equation models and multiple regression equations which incorporate causal paths and the identification of the collective contribution of the three variables (capability, morale and quality of life) in measuring combat readiness. The research selected the survey research that involved cross-sectional studies using a questionnaire for data collection for the formulation of a mathematical model to measure the combat readiness. It opted for the use of Structural Equation Modeling (SEM) as the statistical methodology which takes a hypothesis-testing approach to the analysis of the structural theory bearing on the measure of combat readiness.

\section{Sample:-}

The target population of the survey were the personnel, assets and activities that contributed towards the combat readiness of the studied Armed Force i.e. the Malaysian Army. The type or technique of sampling used was the probability proportionate stratified random sampling. As the population of the studied armed force is known, the computation of the sample size for this research was based on Krejcie \& Morgan (1970) whereby $n=384$.

\section{Measuring Instruments:-}

The measuring instrument used for this research involved the tangible and intangible elements of combat power. For the intangible elements of combat power, the questionnaire on combat readiness, morale, quality of life consisted of 
a 78 items (eight dichotomous and 70 ten-Point Likert-scales) paper and pencil self-report assessment. The length of questionnaire was designed for a completion time of 15 to 20 minutes so as to avoid transient mood states such as boredom and fatigue (Lindell \& Whitney, 2001). The questionnaire was divided into four parts. The first part consisted of eight items on the respondent's background. The second and third parts were on Morale and Quality of life respectively. Where else the fourth part was on Combat Readiness. For the tangible elements of combat power, the data were retrieved in the form of instrument data, observation checklists or numeric records such as units' ledgers, soldier's personal particular, medical records and proficiency tests data.

Data collections were done for all the elements of capability namely firepower, human resource, mobility, communication, logistics and training.

\section{Statistical Treatment:-}

This research involved modeling the theorized relationships among the hypothetical constructs depicted in the earlier outlined theoretical framework with the intention to confirm the combat readiness model using empirical data. The research selected the use of SEM as the statistical methodology which uses a hypothesis-testing approach to the analysis of the structural theory bearing on the measure of combat readiness. The causal effects of capability, morale and quality of life on combat readiness were represented by a series of regression (structural) equations. For this research, the SEM catered for the multiple regression analyses of factors to predict the combat readiness of the armed force based on the variables of tangible and intangible elements of combat power. The SEM and Analysis of Movement Structure (AMOS) graphic were able to model and analyzed the inter-relationships among latent constructs found in the elements of capability, morale and quality of life.

\section{Findings and Discussion:-}

\section{The Results of the Combat Readiness Model:-}

The overall finding of the results shows the consistency of data with the hypothesized combat readiness final model as shown in Figure 2. The adequate goodness-of-fit shows the model has the plausibility of postulated relations among the variables of capability, morale and quality of life (Kwong, 2015).

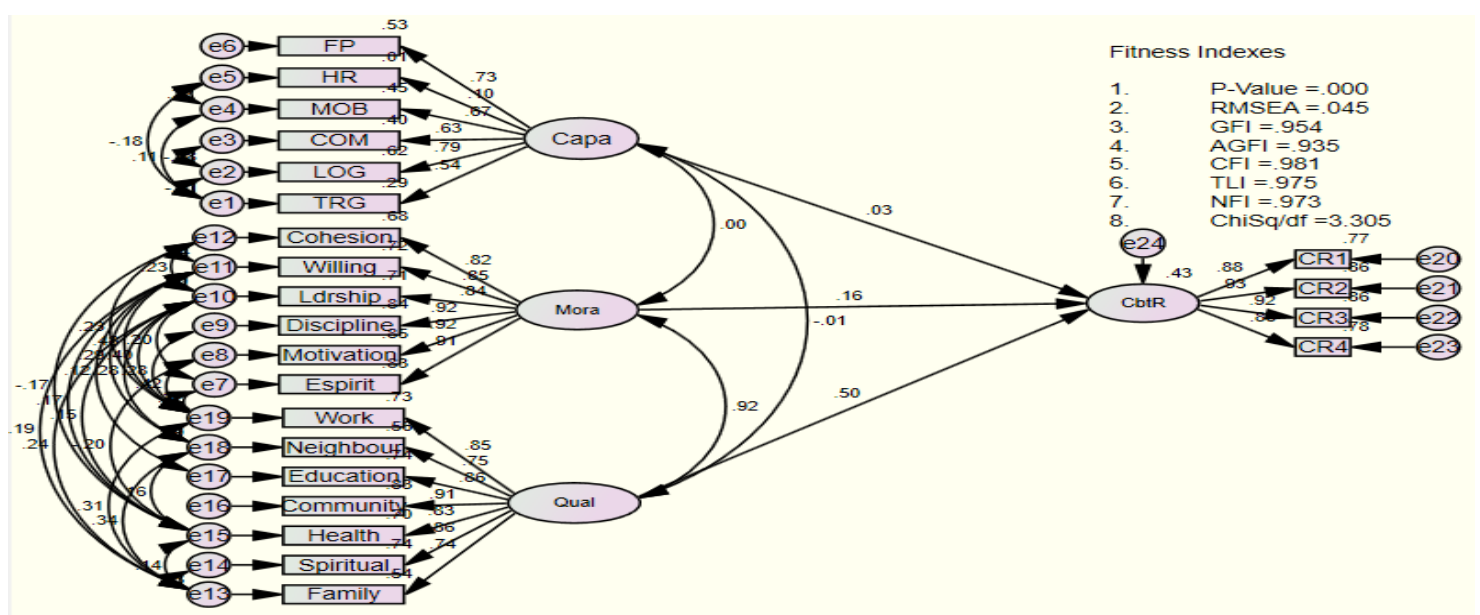

Figure 2:- The hypothesized combat readiness final model

The measure of correlation between the exogenous (independent variable) constructs i.e. morale and quality of life is 0.92 , between capability and morale is 0.00 and between capability and quality of life is -0.01 . These correlation values indicate that morale and quality of life is highly correlated with each other as the intangible elements of combat power. However, the results show that it is difficult to establish the correlation between capability with morale and quality of life. This result is most likely due to the fact that capability makes up the tangible elements of combat power and data for its measurement are obtained from direct input from records that indicate availability of assets. On the other hand, the data of morale and quality of life are measures of attitudes and opinions obtained from questionnaire surveys. The two intangible independent variables/domains used for the measure of combat readiness substantially correlated with high correlation values. 
The value of coefficient of determination $\mathrm{R}^{2}$ is 0.43 , indicating the contribution by the constructs of capability, morale and quality of life in estimating the endogenous (dependent) construct i.e. combat readiness is $43 \%$. In other words, the predictors of combat readiness explain 43 percent of the variance and the error variance of combat readiness.

The truncated results of standardized Beta coefficients $(\beta)$ for the exogenous and endogenous constructs of combat readiness are as presented in Table 3. The three variables capability (Capa), quality of life (Qual) and morale (Mora) are all positively and significantly related to combat readiness (CbtR). When capability goes up by one standard deviation, combat readiness increases by 0.03 standard deviations. Similarly, when morale goes up by one standard deviation, combat readiness goes up by 0.16 standard deviations. Likewise, when quality of life increases by one unit, combat readiness increases by 0.50 standard deviations. Thus, the greater the capability, quality of life and moral of the Malaysian Army, the greater is its combat readiness.

Table 3:- The standardised regression weights.

\begin{tabular}{|c|c|c|c|}
\hline Path & & & Estimate \\
\hline CbtR & $<---$ & Capa & .029 \\
\hline CbtR & $<---$ & Mora & .158 \\
\hline CbtR & $<---$ & Qual & .504 \\
\hline
\end{tabular}

The regression weights for the measure of Beta $(\beta)$ estimate in its actual unit are presented in Figure 3 below. Thus, the mathematical formula for measuring combat readiness for this armed force is represented by the formula $\mathrm{Y}=$ $\beta_{1} X_{1}+\beta_{2} X_{2}+\beta_{3} X_{3}$. The tangible and intangible elements of combat power contribute towards the measure of combat readiness with regression weights of the independent variables capability $\left(\beta_{1}\right)$, morale $\left(\beta_{2}\right)$ and quality of life $\left(\beta_{3}\right)$.

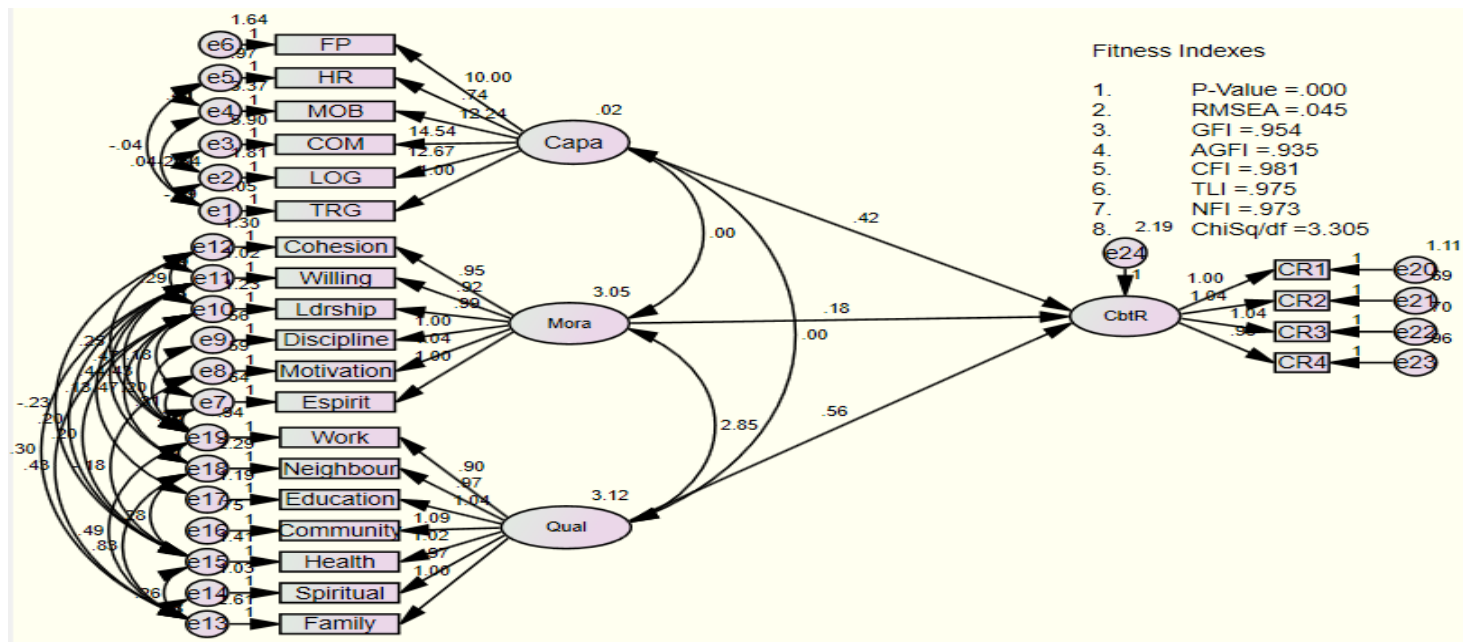

Figure 3:- The regression weights of combat readiness for the measures of Beta $(\beta)$ estimate in its actual unit

The regression weights for morale, quality of life and capability in predicting combat readiness were derived from the estimated unstandardised regression coefficient obtained from the regression weights table as presented in the truncated results of Table 4. For morale, the standard error of regression weight 0.082 of morale on combat readiness indicates the regression weight estimate, 0.176 has a standard error of about 0.082 . The standard error of coefficients represents the expected variation of the estimated coefficients and is an index of the "efficiency" of the predictor variables in predicting the endogenous variable whereby the smaller the standard error, the more efficient the predictor variable (Ho \& Naughter, 2006). The critical ratio value of 2.158 shows that the regression estimates of moral on combat readiness estimate is 2.158 standard errors ( $\mathrm{z}$ ) above zero which is an admissible value as it is above 1.96. The critical ratio is a test of the significance of path coefficients. A critical ratio that is more extreme than \pm 1.96 indicates a significant path $(p<0.05)$ (Ho \& Naughter, 2006). The level of significance for the regression weight for morale on combat readiness indicates the probability of getting a critical ratio 2.158 in absolute value is 0.031 . In other words, the regression weight for morale in predicting the combat readiness is significantly different from zero at the 0.031 level. 
Table 4:- The regression weights for morale, quality of life and capability in predicting combat readiness

\begin{tabular}{|l|l|l|r|r|r|r|r|}
\hline & & & Estimate & S.E. & C.R. & P & Label \\
\hline CbtR & $<---$ & Capa & .416 & .359 & 1.159 & .247 & par_20 \\
\hline CbtR & $<---$ & Mora & .176 & .082 & 2.158 & .031 & par_21 \\
\hline CbtR & $<---$ & Qual & .558 & .084 & 6.684 & $* * *$ & par_22 \\
\hline
\end{tabular}

For quality of life, the standard error of regression weight 0.084 of quality of life on combat readiness indicates the regression weight estimate, 0.558 has a standard error of about 0.084 . The critical ratio value of 6.684 shows the regression estimates of morale on combat readiness estimate is 6.684 standard errors above zero which is an admissible value as it is above 1.96. The level of significance for the regression weight for quality of life on combat readiness indicates the probability of getting a critical ratio 6.684 in absolute value is 0.000 . For capability, the standard error of regression weight 0.359 of capability on combat readiness indicates the regression weight estimate, 0.416 has a standard error of about 0.359 . The critical ratio value of 1.159 shows the regression estimates of moral on combat readiness estimate is 1.159 standard errors above zero which is an inadmissible value as it is below 1.96. The level of significance for the regression weight for capability on combat readiness indicates the probability of getting a critical ratio 1.159 in absolute value is 0.247 . In other words, the regression weight for morale in predicting the combat readiness is significantly different from zero at the 0.247 level. Based on the criteria of standard error and critical ratio, morale and quality of life are highly significant predictors of the combat readiness of the Malaysian Army.

The next findings from the AMOS Text Output is on the standardised residual covariance in examining the fitness of the combat readiness structural model. The residual covariance is the difference between the sample covariance and the model-implied covariance. The combat readiness model is correctly specified as all the standardized residuals are $<2$ in absolute value (Byrne, 2010).

\section{Goodness-of-Fit of the Combat Readiness Structural Model:-}

The fitness indices assessment for the combat readiness structural model shown in Table 5 below indicates the model fits its data. As the values are consistent for a fitting model, the hypothesized combat readiness model represents a generally good fit to the data.

Table 5:- The fitness indices of Combat Readiness Structural Model

\begin{tabular}{|c|c|c|c|}
\hline Category & Index & Index Value & Comments \\
\hline 1.Absolute fit & RMSEA & 0.045 & The required level is achieved \\
\hline & GFI & 0.954 & The required level is achieved \\
\hline 2.Incremental fit & AGFI & 0.935 & The required level is achieved \\
\hline & CFI & 0.981 & The required level is achieved \\
\hline & TLI & 0.975 & The required level is achieved \\
\hline & NFI & 0.973 & The required level is achieved \\
\hline 3.Parsimonious fit & ChiSq/df & 3.305 & The required level is achieved \\
\hline
\end{tabular}

Based on these results, improving the morale and quality of life as well as capability can augment the combat readiness of the armed force substantially. Practically, increasing the total effect of capability on combat readiness requires a larger allocation of fund to augment the elements of firepower, human resource, mobility, communication, logistics and training. However, the allocation for purchase of the tangible elements of capability is often constrained by limited budget. Hence, the next viable option to improve the combat readiness is by improving the intangible elements of morale and quality of life that require a lesser amount of fund compared to the high costs of purchasing the tangible assets for capability. With the allocation of the budget for capability that tend to remain similar (constant) yearly, increasing the total effect of morale and quality of life would produce a higher combat readiness.

\section{Hypotheses Test Results:-}

The hypothesis testing for the combat readiness model as shown in Table 6. These results are in accordance with the findings of previous studies and research. There is a direct relationship between the variables of capability, morale and quality of life with combat readiness. There is also a strong relationship between the two intangible elements of combat power namely, morale and quality of life. However, the $p$ values of the relationship between the tangible 
with the intangible elements are not significant due to the fact that the data of capability are non-normally distributed data obtained from records while the normally-distributed data of the intangible elements were obtained from survey questionnaires.

Table 6:- Results of the hypothesis testing of combat readiness.

\begin{tabular}{|l|l|l|l|}
\hline Hypothesis Statement of Path Analysis & Estimate & P-value & $\begin{array}{l}\text { Results on } \\
\text { Hypothesis }\end{array}$ \\
\hline $\begin{array}{l}\text { There is a direct relationship between the capability, morale and quality of } \\
\text { life with combat readiness in the Malaysian Army }\end{array}$ & 0.43 & 0.000 & Supported \\
\hline There is a significant relationship between morale and combat readiness & 0.176 & 0.031 & Supported \\
\hline There is a significant relationship between capability and combat readiness & 0.416 & 0.247 & Not significant \\
\hline $\begin{array}{l}\text { There is a significant relationship between quality of life and combat } \\
\text { readiness }\end{array}$ & 0.558 & 0.000 & Supported \\
\hline There is a significant relationship between morale and quality of life & 0.925 & 0.000 & Supported \\
\hline There is a significant relationship between morale and capability & 0.004 & 0.904 & Not significant \\
\hline There is a significant relationship between capability and quality of life & -0.003 & 0.715 & Not significant \\
\hline
\end{tabular}

\section{Conclusion:-}

The aim of this research is the development of an integrative model for measuring combat readiness in an armed force. The new integrative model that was developed represents a theory on the measure of combat power and its readiness that is more comprehensive and accurate for an armed force. As each model or theory generates its own covariance matrix (Tabachnick \& Fidell, 2014), this research establishes an estimated population covariance matrix that is most consistent with the sample covariance matrix that is evaluated using SEM-AMOS.

The research contributes to the theoretical knowledge through the explanation of the relationships of capability, morale and quality of life. From the theories and doctrine of warfare, this research provides the domains and subdomains of combat power as the research has managed to establish and verify the components of tangible and intangible elements of combat power that could be used to measure the combat readiness. From the practical perspective, this research contributes towards the management practice of an armed force in terms of gathering data and measuring the combat readiness. The contribution of the research is that the list of items for morale and quality of life in the survey questionnaire could be used to gather data for the measurement of combat readiness while maintaining the current practice of recording data for capability. Based on these data, the combat readiness can then be predicted by using the established mathematical formula. This research has major impacts on management policy setting and decision making whereby commanders can improve the combat readiness of his force by appropriately prioritizing and allocating its resources that could enhance combat readiness.

The research indicates that the construct of quality of life on combat readiness is substantially higher than morale and capability. Based on these results, improving the morale and capability to match the effect generated by quality of life on the combat readiness can augment the combat readiness substantially. Practically, increasing the total effect of capability on combat readiness requires a larger allocation of fund to augment the elements of firepower, human resource, mobility, communication, logistics and training. Hence, an alternative viable option to improve the combat readiness is by improving the intangible elements of morale and quality of life that require a lesser amount of fund compared to the high cost of capital outlay for the tangible assets of capability. Thus, it can be concluded that the results of this research has drastic implications on the policy setting and decision making. The model and formula would be able to provide details of the status of combat readiness of the tangible and intangible elements of combat power. As such, the contributions of each of the elements in the overall combat readiness could be determined. If there is any drastic shortfall observed, the armed force will be able to decide on a new policy that could be implemented to arrest the decline in its combat readiness. The details provided by this combat readiness model would allow the streamlining and prioritizing of allocation of its resources for mitigating the shortfalls and challenges.

All in all, this research is able to address the need for a more comprehensive measure of combat readiness in an armed force. However, there are still areas that could be improved. It is recommended that a research on the combat readiness using the same theoretical framework is carried out but the sampling and analysis have to be based on the components of combat element, combat support and combat service support elements of the armed force. This will 
provide the relationships between the three elements which the armed force could focus its effort on for a better combined arms approach towards combat readiness.

\section{Acknowledgments:-}

The author extends his utmost gratitude to the Malaysian Armed Forces and the Malaysian Army for sponsoring his studies. Appreciation is also extended to the Ministry of Higher Education and the National Defence University of Malaysia for his inclusion as a member of the Fundamental Research Grant Scheme research project on morale, Long Range Research Grant Scheme on technology transfer and the Niche Research Grant Scheme project on morale.

\section{References:-}

1. Andrews, F.M., \& Withey, S.B. (1976). Social indicators of well-being: The development and measurement of perceptual indicators. New York: Plenum.

2. Andrews, R.P., \& Shambo, J.F. (1980). A system dynamics analysis of the factors affecting combat readiness (Unpublished Master's thesis). Air Force Institute of Technology, Ohio. Retrieved from http://www.dtic.mil/dtic/tr/fulltext/u2/a089364.pdf

3. Bester, P.C., \& Stanz, J.K. (2007). The conceptualization and measurement of combat readiness for peace support operations- an exploratory study. SA Journal of Industrial Psychology, 33 (3), 68-78.

4. Betts, R.K. (1995). Military Readiness: Concept, choices, consequences. Washington DC: Brookings Inst Pr. Retrieved from http://trove.nla.gov.au /work/31624781?q\&version Id=38339409

5. Blishen, B., \& Atkinson, T. (1980). Anglophone and Francophone Differences in Perception of the Quality of Life in Canada. In A. Szalai \& F.M. Andrews (Eds.), The Quality of life: Comparative studies (pp. 25-39). London: Sage Publications. Retrieved from http://trove.nla.gov.au/work/ 10038628?q\&versionId=11661889

6. Byrne. B. (2010). Structural equation modeling with AMOS. New York: Routledge.

7. Campbell, A., Converse P.E \& Rodgers, W. (1976). The quality of American life: Perceptions, evaluations and satisfactions. New York, Russell Sage Foundation.

8. Clausewitz, C.V. (1874). On nature of war. Trans. and ed. J. Graham. London: Penguin Group, p.51. Retrieved from http://www.gutenberg. org/files/1946/1946-h/1946-h.htm

9. Filjak, T., \& Denacic, D. (2005). Terrorism fighting readiness - Related to "classic" psychological combat readiness in the Croatian Armed Forces. (Unpublished thesis). Ministry of Defence, Zagreb.

10. Fils, J.F. (2006). The measurement of morale among Belgian military personnel deployed in crisis operations: A longitudinal survey design. In Human Dimensions in military operations - Military leaders' strategies for addressing stress and psychological support (pp.28-1, 28-8) Meeting Proceedings RTO-MP-HFM-134-134, Paper 28. Neuilly-sur-Seine, France: RTO. Retrieved from http://www.rto.nato.int/abstracts.asp.

11. Gal, R. (1986).Unit morale: From a theoretical puzzle to an empirical illustration - An Israeli example. Journal of Applied Social Psychology, 16(6), 549-564.

12. Gal, R., \& Manning, F. (1987). Morale and its components: A cross national comparison. Journal of Applied Social Psychology, 369-391.

13. Goyne, A. (2004). Measuring unit effectiveness: What do commanders want to know and why? Psychology Research and Technology Group, Australian Army. Retrieved from http://www.internationalmta.org/ Documents/2006/2006011P.pdf

14. Griffith, S. (1971). Sun Tzu: The art of war (pp. 114). New York: Oxford University Press.

15. Griffith, J. (2002). Multilevel analysis of cohesion's relation to stress, well-being, identification, disintegration, and perceived combat readiness. Military Psychology, 14(3), 217-239.

16. Hair, J.F., Wolfinbarger Celsi, M.A., Money, H., Samouel, P. \& Page, M.J. (2011). Essentials of business research methods. Armonk, New York: Sharpe.

17. Ho, K., \& Naughter, J.R. (2000). Outliers lie: An illustrative example of identifying outliers and applying robust methods. Multiple Linear Regression Viewpoints, 26(2), 2-6.

18. Ingraham, L.H., \& Manning, F.J. (1981). Cohesion: Who needs it, what is it and how do we get it to them? Military Review, June 1981, 2-21.

19. Interfax: Russia and CIS Military Daily (Moscow), (2011). Retrieved from Report information for ProQuest on 10 October 2013.

20. Johnston, B.F., Brown, K.J., Cole, A.K., \& Agrawal, S. (2002). Measuring organizational climate in the Canadian Forces (Unpublished manuscript). Retrieved from http://www.internationalmta.org/ Documents/2006/ 2006011P.pdf 
21. Knorr, K.E. (1956). The war potential of nations. New Jersey: Princeton University Press.

22. Krejcie, R., \& Morgan, D. (1970). Determining sample size for research activities. Educational and Psychological Measurement, 30, 607-610.

23. Kruys, G.P.H. (2001). Combat readiness with specific reference to armies. In M. Hough and L. du Plessis (Eds.), Selected military issues with specific reference to Republic of South Africa (pp. 87-105). Pretoria: Institute for Strategic Studies.

24. Kwong, F.W., Nor, N.M. \& Lee, L.S. (2013). A Survey on the measure of combat readiness. Statistics and Operation Research 2013 Records of Proceeding. Citation: AIP Conference Proceedings 1613, 3 (2014); doi: $10.1063 / 1.4894326$

25. Kwong, F.W., Nor, M.N., Jegak Uli \& Inderjit Singh Tara Singh. (2014). Conceptualising the measure of combat readiness by incorporating the tangible and intangible elements of combat power. $6^{\text {th }}$ International Conference on Humanities and Social Sciences Conference Proceeding. Zulfaqar Int. J. Polit. Def. Secur. 1(2).

26. Kwong, F.W. (2015). Integrative model of the tangible and intangible elements of combat power for the Malaysian Army combat readiness. National Defence University of Malaysia, Kuala Lumpur, Malaysia.

27. Likert, R. (1967). The human organization. New York: McGraw-Hill.

28. MacDonough, T.S. (1991). Noncombat stress in soldiers: How it is manifested, how to measure it and how to cope with it. In R. Gal \& A.D. Mangelsdorff (Eds.), Handbook of Military Psychology, (pp.507-530). New York: John Wiley \& Sons.

29. McKennell, A.C. (1978). Cognition and affect in perceptions of well-being. Social Indicators Research, 5, 389426. Retrieved from deepblue.lib. umich. edu/.../11205_2004_Ar

30. Meijer, M., \& de Vries, R. (2005). Maintaining Combat readiness in the Royal Netherlands Armed Forces: The psychosocial perspective. Strategies to maintain combat readiness during extended deployments - A human systems approach (pp. 10-1, 10-8). Meeting proceedings RTO-MP-HFM-124, Paper 10. Neuilly-surSeine, France: RTO.

31. Moscow Times, (2016, June 14). Russia military begins surprise inspections for 'combat readiness', Moscow Times. Retrieved from https://themoscowtimes.com/articles/russian-military-begins-surprise-inspections-forcombat-readiness-53287

32. Mumford, S.J. (1976). Human resource management and operational readiness as measured by refresher training on navy ships. San Diego: Navy Personnel Research and Development Center. Retrieved from www.dtic.mil/cgi-bin/GetTRDoc?AD=ADA022372

33. Murphy, P.J., \& Farley, K.M.J. (2002). Morale, cohesion and confidence in leadership: Unit climate dimensions for Canadian Soldiers on operations. In C. McCann \& R. Pigean (Eds.), The human in command: Exploring the modern military experience. New York: Kluwer Academic/Plenum Publishers. Retrieved from http://www.springer.com/psychology/book/978-0-306-46366-2

34. Nkewu, Z. (2014). Impact of psychological wellbeing and perceived combat readiness on willingness to deploy in the SANDF: An exploratory study (unpublished Master dissertation). Stellenbosch University, South Africa.

35. Nor, N.M. \& Wand, K. (2001). Weapon Scoring Using a Multilayer Perceptron Network, Battlefield Technology, 4(1), 7-13.

36. Nunnally, J.C., \& Bernstein, I.H. (1994). Psychometric theory, (3 ${ }^{\text {rd }}$ ed.)(pp. 275-278). New York: Mac-Graw Hill. Retrieved from http://psychology.concordia.ca/fac/kline/library/k99.pdf

37. Richardson, F.M. (1978). Fighting spirit: A study of psychological factors in war. London: Leo Cooper.

38. Rosenberger, J.D. (1999). Reversing the Downward Spiral of Combat Readiness: Change the way we measure it. Military Review, 79(6), 54.

39. Schumm, W.R., Bell, D.B., Rice, R.E. \& Schuman, P.M., (1996). Marriage trends in US Army. Psychological Reports, 78, 771-784. Retrieved from www.healthymarriageinfo.org/resource-detail/ download.aspx?id=288

40. Shamir, B., Brainin, E., Zakay, E., \& Popper, M. (2000). Perceived combat readiness as collective efficacy: Individual- and group-level analysis. Military Psychology, 12(2), 105-119.

41. Siebold, G. L., \& Manning, F.J. (1999). The Evolution of the Measurement of Cohesion. Military Psychology, 11(1), 21-22.

42. Summers, H. (1998). Military and C4i, Retrieved from http://www.infowar.com/mil_c4i/mil050298c_j.shtml

43. Tabachnick, B.G., \& Fidell, L.S. (2014). Using multivariate statistics. (6th ed.)(pp. 159). Boston: Pearson Education, Inc.

44. Taylor, J.C., \& Bowers, D.G. (1972). Survey of organizations: A machine-scored standardized questionnaire instrument. Ann Arbor: Institute for Social Research, University of Michigan. 
45. United States Department of Defense. (2010), Dictionary of Military and Associated Terms, JP 1 (02) (pp. 229). Pentagon, Washington: Joint Chiefs of Staff.

46. United States Department of Defence. (2010). CJSC Guide to the Chairman's Readiness System. United States of America: Joint Chief of Staff, p A-2. Retrieved from http://www.dtic.mil/cjcs_directives /cdata/unlimit/g3401.pdf

47. United States Department of Army. (n.d.). Force Readiness, Field Manual 100-11, United States.

48. Voith, M.R. (2001). Military Readiness. The Army Doctrine and Training Bulletin, 4(2).

49. Van Vuuren, L. (2000). Report by IG on readiness in SANDF, Pretoria, South Africa Department of Defence.

50. Verwayen, H. (1980). The specification and measurement of the quality of life in OECD countries. In A. Szalai and F.M. Andrews (Eds.), 7he Quality of Life: Comparative Studies (pp. 235-247). London: Sage.

51. Vinson, M.E. (2000). Structuring the army for full-spectrum readiness. Parameters, XXX (2), 19-32.

52. Wolosin, D.G., Wilcove, G.L., \& Schwerin, M.J. (2003). An exploratory Model of Quality of Life in the U.S. Navy. Millington, Tennessee: Navy Personnel Research Studies and Technology. Military Psychology, 15(2), 133-152.

53. Yurechko, JJ. (2007).The Soviet combat readiness system, London: Routledge. The Journal of Soviet Military Studies, 231-242.

54. Zapf, W. (1980). The SPES social indicators system in comparative perspective. In A. Szalai \& F.M. Andrews (Eds.), The Quality of Life: Comparative Studies (pp. 249-269). London: Sage Publications. Retrieved from http://trove.nla.gov.au/work/10038628?q\&versionId =11661889 